\title{
KOMUNIKASI MASSA DALAM MEDIA CRITICAL DAN MEDIA EQUATION
}

\author{
Bahtiar, MA \\ Institut Agama Islam Negeri Langsa \\ Email.mrlungs@yahoo.com
}

\begin{abstract}
Abstrak
Banyak para ahli komunikasi dunia memberikan pandangan tentang komunikasi massa secara beragam. Semua dilakukan berdasarkan sudut pandang masing-masing untuk melahirkan sebuah pemahaman yang konkrit, jelas dan mudah dipahami oleh semua kalangan terkait komunikasi massa. Diantara ahli komunikasi yang meyampaikan defenisi komunikasi massa untuk diketahui dan dipahami khalayak adalah Bittner mengatakan "komunikasi massa adalah pesan yang dikomunikasikan melalui media massa pada sejumlah besar orang (massa communication is meseeges communicated through a mass medium to a large number of people)

Dalam ilmu jurnalistik, media massa yang menyiarkan berita atau informasi disebut juga dengan istilah pers. Menurut undang-undang pokok pers nomor 40 tahun 1999 pasal 1 ayat (1) pers adalah lembaga social dan wahana komunikasi massa yang melaksanakan kegiatan jurnalistik meliputi mencari, memperoleh, memiliki, menyimpan, mengelola dan menyampaikannya sebagai informasi, baik dalam bentuk tulisan, suara, gambar, suara gambar serta data dan grafik menggunakan media massa. Misi yang diemban oleh media massa adalah mengamankan, menjunjung dan menyukseskan pembangunan nasional.

Dari defenisi yang diungkapkan oleh para ahli tersebut, maka dapat kita pahami secara sederhana bahwa komunikasi massa adalah proses penyampaian pesan dari seorang komunikator kepada komunikan (khalayak banyak) melalui saluran media massa baik berupa cetak, online, radio dan televisi. Namun dalam pemahaman komunikasi massa, setiap pesan yang disampaikan berisi informasi atau berita penting bagi masyarakat, baik berupa pengumuman, pendidikan, pengetahuan, maupun informasi social, hukum, politik dan budaya yang terjadi dalam kehidupan kita. Bukan pesan (komunikasi) sebagaimana percakapan rutin yang dilakukan oleh dua orang atau lebih di warung atau rumah.

Media massa sebagai saluran atau sarana komunikasi telah mengalami perkembangan yang signifikan dari waktu ke waktu, mulai dari surat kabar cetak harian (koran), majalah, berkembang ke era frekuensi atau radio, selanjutnya era signal atau televisi dan kini era jaringan atau internet. Perkembangan media massa ini secara positif semakin memudahkan manusia melakukan berbagai komunikasi terbuka secara massif untuk penyebaran informasi. Namun secara negative, perkembangan teknologi media massa ini juga telah merusak bahkan memutuskan hubungan interaksi social masyarakat. Bahkan manusia cenderung lebih memilih media sebagai sarana untuk berkomunikasi daripada bertemu langsung dan menyampaikan pesan (komunikasi interpersonal).
\end{abstract}

\section{Kata Kunci: Komunikasi Massa, Media Critical, Media Equation}

\section{A. Media Massa Sebagai Sarana Komunikasi}

Seiring perkembangan jaman dan teknologi, keberadaan media massa telah menjadi bahagian yang tidak terpisahkan dalam kehidupan manusia. Selain sebagai sumber informasi, media massa juga telah menjadi salah satu saluran komunikasi bagi masyarakat untuk menyampaikan berbagai kritikan, teguran, masukan atau solusi kepada pemerintah. Juga sebagai saluran untuk memberikan berbagai penjelasan (interpretative) terkait sebuah situasi kepada masyarakat dalam bentuk opini atau artikel. 
Paryati Sudarman dalam bukunya "Menulis di Media Massa"mengatakan bahwa fungsi dari media massa dalam kehidupan manusia adalah untuk menginformasikan (to inform) peristiwa atau hal penting yang perlu diketahui oleh khalayak ramai, untuk mendidik (to educate) sebagai upaya mendorong perkembangan intelektual masyarakat dan membentuk watak kritis masyarakat, untuk menghibur (to intertaint) agar dapat melunakkan potensi pertentangan atau friksi terkait suatu peristiwa yang memunculkan pertentangan.

Juga untuk mempengaruhi (to influence) pembaca baik bersifat pengetahuan, perasaan maupun tingkah laku, untuk respon social (to social responcibility) agar masyarakat pembaca dapat menanggapi tentang suatu fenomena social yang terjadi dengan berbagai reaksi, dan untuk penghubung (to linkage) antara masyarakat dengan pemerintah terkait berbagai aspirasi masalah pembangunan, kesejahteraan dan keadilan secara social dan hukum.

Sebagai sarana komunikasi dan informasi, media massa memiliki etika dalam penyampaian tulisan kepada khalayak dengan merujuk pada penulisan standar bahasa Indonesia yang telah dirumuskan dalam Kamus Besar Bahasa Indonesia (KBBI) dan rumus kalimat Subjek, Prediket, Objek, Keterangan (SPOK). Kenneth E Andersen dalam bukunya Introduction to Communication Theory and Partice menyatakan bahwa etika adalah suatu studi tentang nilai-nilai dan landasan mengenai apa itu kebaikan atau keburukan dan bagaimana seharusnya. (Paryati Sudarman, 2008:17)

Dalam penyampaian informasi, media massa dituntut untuk jujur dengan informasi yang disampaikan sesuai dengan peristiwa lapangan, tanpa harus melebih-lebihkan atau mengurangi yang akhirnya berdampak pada biasnya informasi. Juga harus akurat dalam penyampaian informasi menyangkut ketepatan data lapangan agar masyarakat tidak bingung dalam memahaminya. Bebas dan bertanggungjawab terhadap informasi yang disampaikan, artinya bukan atas inisiatif untuk kepentingan seseorang atau kelompok tertentu yang dapat merugikan orang lain. Serta melakukan kritik yang membangun (konstruktif) sebagai fungsi pengawasan media massa dalam upaya mengawal kebijakan pemerintahan berbasis kepentingan dan kemaslahatan rakyat.

Sebagai saluran komunikasi dan informasi, media massa juga harus mampu memilah dan memilih mana komunikasi dan informasi yang layak dan pantas untuk dipublikasikan sebagai konsumtif public. Sehingga setiap komunikasi dan informasi yang disampaikan melalui media massa tidak memunculkan konflik social ditengah masyarakat yang akhirnya dapat berujung padaclass action.

Ada sebuah sikap bijak media massa bersama jurnalisnya yang selalu menjadi pedoman dalam menjalankan tugas selama ini, yaitu "semua yang di tulis (mediakan) wajib diketahui, tapi tidak semua yang diketahui wajib di tulis (mediakan)" artinya dalam penyampaian komunikasi dan informasi, media massa harus benar-benar selektif sebagai sarana komunikasi dan mampu untuk 
memposisikan diri sebagai media intelektual untuk menjaga, mengawal dan melindungi kelangsungan interaksi social masyarakat dalam lingkungan dan pemerintahan.

\section{B. Komunikasi Massa dalam Media Critical}

Selain sebagai sarana komunikasi dan informasi, lahirnya media massa juga didasari pada sebuah usaha waralaba (bisnis) yang bertujuan untuk mencapai keuntungan secara materi (financial). Sebagai usaha untuk penghidupan, maka seorang pemilik modal dari perusahaan media akan melakukan berbagai upaya untuk menjaga kelangsungan usahanya. Termasuk menjaga dan mempertahankan kualitas produk agar terus diminati oleh masyarakat dan mendapatkan pangsa pasar yang luas.

Dalam menjalankan bisnis media massa, sumber pendapatan keuangan adalah modal (investasi), pemasaran (sirkulasi), iklan dan kerjasama. Semua sumber tersebut memiliki pengaruh besar terhadap berita dan informasi yang disampaikan media massa kepada khalayak. Sehingga kondisi ini juga menjadi standar media massa dalam menyampaikan berita dan informasi untuk mendapatkan sasaran dari pemasaran.

Besarnya oplah atau penjualan media massa kepada pembaca (masyarakat) sangat ditentukan oleh kualitas berita dan informasi yang disajikan. Terutama berita-berita dan informasi yang sifatnya mengkritik kebijakan pemerintah yang tidak berpihak pada kepentingan masyarakat, informasi peristiwa-peristiwa besar seperti bencana atau konflik, kasus atau kriminalitas serta informasi lainnya sesuai dengan permintaan pasar. Pendapatan dari penjualan oplah media massa bagi perusahaan media dianggap tidak signifikan untuk menujang operasional tim, sehingga iklan dan kerjasama menjadi andalan penting lainnya untuk menjaga kelangsungan.

Untuk mendapatkan pihak ketiga (mitra) baik pemerintah maupun swasta sebagai pemasang iklan, tentunya media dituntut harus berpihak pada kepentingan mitra. Kondisi ini menjadi dilema yang akhirnya dapat mempengaruhi media sebagai lembaga pengawasan untuk membatasi sikap kritikalnya. Ditambah lagi aturan pemerintah yang mengontrol penyebaran informasi public, sehingga membuat media memiliki ketergantungan lebih kepada mitra untuk mendapatkan kerjasama sebagai pendapatan perusahaan.(Effendi Gazali,victor Menayang,dedy $n$. Hidayat,pinckey triputra,2003:1-15)

Namun demikian, seiring perkembangan teknologi, banyaknya bermunculan media massa telah membuat komunikasi massa semakin mudah dan terbuka bagi masyarakat. Upaya-upaya pembungkaman kritikan media terhadap berbagai kebijakan pemerintah semakin melemah. Sehingga, saat ini media sebagai sarana komunikasi massa semakin terbuka untuk menyampaikan berbagai gagasan, masukan dan kritikan terhadap pemerintah.

Dalam media critical (media critical theory), komunikasi massa menjadi kekuatan utama untuk memperjuangkan hak masyarakat dan membebaskan masyarakat dari penindasan secara 
ekonomi, social, budaya, politik, hokum dan lainnya. Sehingga masyarakat tertindas mendapatkan keadilan dalam status ekonomi, social, budaya, politik, hokum dan lainnya. Nilai kritik media massa yang didasari pada kondisi objektif lapangan dengan akurasi data menjadi senjata bagi masyarakat tertindas untuk mendapatkan keadilan dan kesamaan hak. Sebagaimana kasus yang menimpa nenek Minah di Bayumas beberapa tahun lalu, karena diduga mencuri beberapa tiga buah kakao (coklat) di kebun seorang pengusaha, dia harus menerima hukuman 1 bulan 15 hari penjara (www.News.detik.com:2019) Begitu juga dengan kasus nenek Asyani di Sitobundo, Jawa Timur, karena memiliki tujuh batang kayu jati yang di tuduh hasil illegal loging oleh pihak Perhutani saat membawanya ke tukang kayu untuk dijadikan perabot, maka harus dihukum dengan tuntutan 5 tahun penjara. (www.sp.beritasatu.com:2019)

Mirisnya perlakuan hukum yang dinilai tidak memberikan rasa keadilan bagi rakyat miskin dan tidak mempertimbangkan aspek social ini, maka komunikasi massa dalam media critical menjadi salah satu jalan untuk memperjuangkan keadilan bagi masyarakat miskin. Dengan teori kritis dari media kritikal ini, media dapat memperjuangkan hak masyarakat tertindas tersebut lewat investigative reportase dengan membongkar data dan fakta-fakta yang ada dan mengajak masyarakat luas untuk terlibat dalam memperjuangkan keadilan bagi mereka.

Hal ini sejalan dengan apa yang diungkapkan oleh beberapa tokoh social dalam Media critical Theory seperti Karl Marx, Engels Guevera, Regis, Debay dan pemikiran social lainnya, bahwa rakyat harus dibebaskan dari status quo yang menindas dengan mendobrak system yang korup. Media massa yang telah mempromosikan banyak hal, menjadi salah satu saluran untuk menjalankan teori media kritis tersebut. Karena menurut perspektif teori ini media tidak boleh hanya memberitakan fakta atau kejadian yang justru memperkuat status quo, namun harusmedia harus terus melakukan berbagai kritikan yang akhirnya akan merubah dan melahirkan kesetaraan keadilan yang proporsional.(Khomsahrial Romli,2016:55)

Penerapan media critical dalam memperjuangkan kepentingan masyarakat melalui komunikasi media juga sejalan dengan terapan teori peluru yang dikemukakan oleh Wilbur Schramm, bahwa pesan yang tepat sasaran akan mendapatkan efek yang diinginkan. (Khomsahrial Romli,2016:55) Sebagaimana peluru yang dilepaskan akan mengenai sasaran dan menimbulkan reaksi sesuai dengan sifat peluru, begitu juga halnya dengan pesan yang disampaikan melalui media massa akan langsung menuju masyarakat pembaca dan akan menimbulkan reaksi sesuai isi pesan yang disampaikan.

\section{Komunikasi Massa dalam Media Equation}

Perkambangan teknologi dewasa ini telah menimbulkan ketergantungan manusia terhadap berbagai sarana teknologi untuk kemudahan hidup, termasuk dalam hal teknologi komunikasi dan informasi seperti televisi, internet (IT) dan smartphone. Bahkan sarana teknologi secara tidak 
langsung telah memutuskan mata rantai interaksi social masyarakat dengan lingkungan, manusia lebih memilih sarana teknologi sebagai media untuk berkomunikasi antar individu daripada interaksi langsung. Juga membangun interaksi informasi dengan media secara intens, sehingga menimbulkan sikap percaya dan saling memahami yang akhirnya menganggap bahwa keberadaan media sama dengan real social interaction.

Kedekatan hubungan manusia dengan media (komunikasi) dalam menyikapi berbagai hal dan saling berbagi, akhirnya memunculkan sebuah teori yang menyatakan bahwa media memiliki kesamaan dengan manusia dalam hal komunikasi yaitu Media Equition Theory (Teori Persamaan Media).Tanpa disadari, kedekatan ini membuat manusia begitu cepat merespon berbagai informasi yang disampaikan media seolah-olah dari orang lain yang langsung berada dihadapan. (Nurdin,2014:178) Sementara pada saat itu manusia sedang berinteraksi dengan media sebagai kedekatan komunikasi dan memahaminya.

Tokoh teori ini, Bryon Reeves dan Clifford Nass, memunculkan teori media ekuasi atau persamaan media ini untuk menjawab persoalan mengapa orang-orang secara tidak sadar dan bahkan secara otomatis merespon apa yang dikomunikasikan media seolah-olah media itu manusia. Teori ini memperhatikan bahwa media juga bisa diajak berbicara, media bisa menjadi lawan bicara individu seperti dalam komunikasi antar pribadi yang melibatkan dua orang dalam situasi face to face.

Sikap melihat media sebagai mahkluk yang dapat diajak untuk saling berbagi dan memahami telah menggiring manusia untuk cepat percaya dengan berbagai informasi yang dikomunikasikan oleh media tersebut tanpa harus melakukan kroschek atau klarifikasi (tabayyun) terlebih dahulu. Tidak tertutup kemungkinan media equition (ekuasi) seperti ini akan memunculkan sikap taklit dikalangan manusia yang dapat menggiringnya pada lingkaran komunikasi massa hoaxs (kebohongan).Contoh kasus dugaan penganiayaan dan pengeroyokan terhadap aktivis social Ratna Serumpaet oleh sekelompok orang tidak dikenal saat menuju Bandara Husein Satranegara, Bandung Jawa Barat pada 21 September 2018 lalu.(www.Nasional.sindonews.com:2019)

Informasi ini langsung mendapatkan reaksi masyarakat yang pro terhadap korban dan tentunya masyarakat media ekuasi. Akibatnya, beragam tanggapan, pembelaan dan kutukan terhadap pelaku pengeroyokan dari pemberitaan tersebut menyebar dan menjadi tranding topic. Bahkan beberapa tokoh nasional seperti Prabowo Subianto, Fahri Hamzah, Fadli Zon dan beberapa tokoh perempuan lainnya ikut memberikan tanggapan issue tersebut melalui komunikasi massa. Sementara hasil penyidikan Polri terkait issue tersebut, terungkap bahwa berita kasus pengeroyokan dan penganiayaan terhadap aktivis Ratna Serupaet tersebut Hoaxs. Bahkan yang bersangkutan melalui media massa telah mengakui kesalahannya dan meminta maaf secara terbuka kepada masyarakat lewat komunikasi massa.(www.Aceh.tribunnews.com:2019) 
Dengan media equition, masyarakat tentunya juga akan memahami kesalahan tersebut dan segera meralat persepsi negative yang diterima dari komunikasi media. Melihat dampak dari media ekusi (persamaan media) yang terjadi pada kasus diatas, maka hal ini sangat berpotensi menghancurkan hubungan social masyarakat dalam sebuah Negara. Karena sikap menganggap media sebagai mahkluk, membuat manusia cepat untuk mempercayai hal-hal diluar sana yang belum tentu kebenarannya. Media equition theory telah menempatkan manusia dibawah kendali komunikasi media. Ketakutan besar dari media ekuasi ini dalam perkembangan kehidupan manusia adalah hilangnya rasa percaya manusia terhadap sesamanya dan menjadikan media sebagai rujukan utama untuk menyelesaikan berbagai masalah. Walaupun diketahui bahwa komunikasi media merupakan hasil cipta karya manusia lainnya diluar sana yang juga telah menjadikan media massa sebagai basis komunikasi. Berbagai masalah kehidupan, menyangkut hukum, social, ramalan dan pekerjaan, manusia lebih terbuka berkomunikasi dengan media daripada dengan manusia lainnya sebagai ahli secara langsung. Bahkan ironinya, menyangkut dengan persoalan agama pun, ketergantungan media ini membuat manusia lebih memilih berkonsultasi dengan media (berguru pada ustadz google) daripada dengan manusia langsung sebagai sumber ilmu.

Padahal Bernad berelson dan Gary A. Steiner telah mengungkapkan bahwa komunikasi merupakan transmisi informasi, gagasan, emosi, ketrampilan dan sebagainya dengan menggunakan kata-kata, symbol, gambar, figure, grafik danlainnya.(B.Aubrey Fisher, 1978:5) Dari pernyataan ini dapat dipahami bahwa komunikasi yang baik dalam membangun interaksi social adalah berhubungan langsung antara dua orang atau lebih dan melakukan komunikasi dengan melibatkan semua ekpresi diri (komunikasi interpersonal). Karena pemaknaan dari kalimat bukan hanya sebatas ungkapan, tapi juga membutuhkan unsur intonasi, gesture dan observasi. Hal ini tidak bisa didapatkan dalam komunikasi media yang disampaikan satu arah sebagaimana teori peluru, bahwa sasaran (komunikan) hanya menerima pesan dan menalarnya sendiri. Jadi komuniasi media dalam media equation sangat berpotensi terjadinya penyimpangan pemaknaan pesan.

Komunikasi massa media ekuasi menjadi sebuah alternantif untuk menghindari benturan ketika seseorang ingin menyampaikan pesan kepada khalayak. Karena dalam media ekuasi ini seorang komunikator hanya butuh respon dari media yang dimanfaatkannya. Media ekuasi membuat psikologi manusia bagaikan hidup dalam halusinasi, dimana perangkat media komunikasi jaringan internet seperti smartphone (gawai), computer, laptop seakan hidup dan menjadi teman komunikasi aktif dalam berbagai hal, baik informasi, silang pendapat bahkan mencari rujukan kebenaran sebuah sikap permasalahan.

Media akuasi juga menimbulkan kecenderungan masyarakat untuk apatis terhadap lingkungan dan pemerintahan. Karena ketimpangan dalam penegakan hokum atau perlakuan yang tidak adil dalam layanan, akhirnya mengikis rasa kepekaan terhadap manusia dan lebih memilih media sebagai teman untuk mengeluh dan menumpah berbagai permasalahan hidup. Karena semua 
jawaban dari persoalan kehidupan manusia didapatkan dalam media yang merupakan hasil record dari pernyataan atau tanggapan masa lalu yang dimunculkan kembali sebagai solusi terbaru.

\section{Penutup}

Komunikasi massa dalam media critical dan media equation sebagai teori baru dalam komunikasi massa berjalan seiring pada porosnya untuk memenuhi hasrat dan keinginan manusia selaku komunikator dan komunikan untuk saling mempengaruhi dan saling berbagi. Dimana dalam media critical manusia dituntut untuk lebih peka dengan kondisi social kemasyarakat yang berlandaskan pada prinsip keadilan dan kesetaraan.

Juga dituntut berada pada pihak kaum lemah untuk menjadi kekuatan memperjuangkan dan membebaskan masyarakat dari penindasan pemerintahan atau pemangku kekuasaan. Sehingga masyarakat sebagai objek dari sasaran kebijakan mendapatkan hak keadilan dan kesetaraan sebagai manusia yang merdeka dan berdaulat diatas bangsanya. Tidak ada lagi kehidupan yang mempertahankan status quo bahwa kaum ningrat mendapatkan perlakuan istimewa atas kesalahannya, sementara kaum sudra mendapatkan perlakuan yang sebaliknya.

Kondisi ini persis seperti ketimpangan perlakuan beberapa lembaga pemasyarakatan terhadap warga binaan. Bagi warga binaan yang memiliki kemampuan ekonomi akan mendapatkan penempatan pada kamar tahanan istimewa seperti hotel berbintang. Sementara warga binaan kelas teri hanya mendapatkan kamar tahanan seadanya dan selayaknya kamar tahanan pada umumnya. Kondisi ini dalam media critical menuntut adanya pembebasan dan perjuangan hak-hak yang sama dengan konsep keadilan dan media dituntut berani melawan dan menyampaikan informasi yang berpihak pada rakyat kecil.

Sementara dalam media equation atau ekuasi, manusia dihadapkan pada sikap memahami media lebih sekedar perangkat atau sarana. Bahkan pada tingkatan tertentu media berafiliasi sebagai sosok mahkluk yang dapat diajak untuk berkompromi dan saling berbagi. Media akuasi dianggap lebih memahami kondisi social kehidupan manusia, sehingga berbagai solusi cenderung lebih mengedepankan saran media daripada interaksi langsung dengan manusia lainnya sebagai bahagian lengkap dari proses komunikasi antar manusia dalam interaksi social. 


\section{DAFTAR KEPUSTAKAAN}

Effendi Gazali, Victor Menayang, Dedy N. Hidayat, Pinckey Triputra, Konstruksi Sosial Industri Penyiaran, Jakarta : Departemen Ilmu Komunikasi FISIP UI, 2003

Fisher, B. Aubrey, Teori-TeoriKomunikasi,Bandung : Remaja Rosdakarya, 1978

https://news.detik.com/berita/1244955/mencuri-3-buah-kakao-nenek-minah-dihukum-1-bulan-15hari, akses 3 Septermber 2018

http://sp.beritasatu.com/home/nenek-asyani-ditahan-labora-malah-dapat-surat-bebas/81922, akses 3 Septermber 2018

https://nasional.sindonews.com/read/1342848/13/ratna-sarumpaet-dikabarkan- dikeroyok-orangtak-dikenal-1538455680, diakses 3 September 2018

http://aceh.tribunnews.com/2018/10/03/berbohong-telah-dikeroyok-ratna-sarumpaet-menangisminta-maaf-kepada-prabowo, diakses 3 September 2018

Nurudin, Pengantar Komunikasi Massa, Jakarta : Rajawali Pers, cetakan ke-6, 2014

Romli,Khomsahrial.Komunikasi Massa,Jakarta : Gramedia Widiasarana Indonesia, 2016

Sudarman,Paryati.Menulis di Media Massa,Yogyakarta : Pustaka Pelajar, 2008 